\title{
KINEZITERAPIJOS NAMŲ PROGRAMOS POVEIKIS LEUKEMIJA SERGANČIŲ VAIKŲ FIZINEI IR FUNKCINEI BŪKLEI
}

\author{
Giedrė Juškẻnienė, Karina Miliškevičiūtė, Aurelija Šidlauskienė \\ Vilniaus universiteto Medicinos fakulteto Reabilitacijos, fizinès ir sporto medicinos katedra
}

Raktažodžiai: onkohematologija, pediatrija, leukemija, kineziterapija, raumenu jèga, judesių amplitudè, funkcinè būklè.

\section{Santrauka}

Tyrimo tikslas: įvertinti 8 savaičių kineziterapijos namų programos efektyvumą leukemija sergančių vaikų fizinei būklei. Tyrimo metodai: iš viso tyrime dalyvavo 16 leukemija sergančių vaikų, tiriamųjų amžiaus vidurkis - $10,81 \pm 3,83$ metai. Tyrimas buvo atliekamas Vilniaus universiteto Vaikų ligoninès onkohematologijos skyriuje nuo $2014 \mathrm{~m}$. lapkričio iki $2015 \mathrm{~m}$. balandžio ménesio.

Tyrimui atlikti buvo panaudota centimetrinè juostelè, kuria išmatuotos kūno apimtys (šlaunų, liemens, dubens) bei krūtinès ląstos ekskursija. Tiriamųjų pėdos dorzalinès fleksijos ir šlaunies vidinès bei išorinès rotacijų amplitudès matuotos goniometru. Pèdos dorzalinę fleksiją ir blauzdos tiesimą atliekančių raumenu jèga vertinta pagal R. Lovett testą. Taip pat tiriamieji atliko 3 metrų „Stotis ir Eiti“ bei modifikuotą funkcini judejimo testus.

Duomenų analizè atlikta naudojant statistinès analizès Excel 2007 bei „R-3.2.0 for Windows“ programas. Rezultatai: kineziterapijos namų programos taikymas 8 savaites leukemija sergantiems vaikams yra efektyvi priemonè, siekiant koreguoti kūno antropometrinius duomenis, didinti sumažejusias judesių amplitudes ir raumenų jègą bei gerinti „Stotis ir Eiti“ testo ir modifikuoto Keitel indekso rezultatus.

Išvados. Po 8 savaičių kineziterapijos namų programos taikymo leukemija sergantiems vaikams statistiškai reikšmingai padidejo krūtinès ląstos ekskursija, sumažéjo šlaunų, liemens ir dubens apimtys, padidejo vertintų sąnarių judesių amplitudès, raumenų jèga, pagerèjo "Stotis ir Eiti" testo bei modifikuoto Keitel indekso rezultatai. Gauti rezultatai leidžia daryti prielaidą apie pagerejusią tiriamujų pusiausvyrą bei funkcinę būklę.
Ivadas

Ūminè limfoblastinè leukemija - tai piktybinè kraujodaros sistemos liga, kuomet kaulų čiulpuose nekontroliuojamai dauginasi nesubrendusios limfocitų formos [1]. Ūminè limfoblastinè leukemija dažniausia vaikų onkologinè liga, kuri sudaro 26 proc. visų vaikams diagnozuojamų vėžio atvejų [2]. 5 metų išgyvenamumas po ūminès limfoblastinès leukemijos gydymo šiuo metu siekia apie 88 procentus [1]. Vis dèlto pailgèjusi gyvenimo trukmè šiems asmenims turi ir neigiamų pasekmių. $75 \%$ išgyvenusiųų asmenų turi lètinių sveikatos problemų, lemiančių didesnị sergamumą bei mirtingumą nuo širdies ir kraujagyslių, metabolinių ligų [3]. Stebimi ir kiti neigiami požymiai: sumažejęs fizinis pajègumas, sumažejusi raumenų jẻga, raumenų elastingumo ir sąnarių amplitudžių sumažejimas, pusiausvyros ir eisenos sutrikimas, nutukimas, sumažèjęs kaulų tankis, nuovargis, miego sutrikimai, II tipo cukrinis diabetas, kvèpavimo sistemos ligos ir psichosocialinès problemos [4]. Vinkristino sukelta polineuropatija viena vis dažniau atpažistamų vẻlyvujjų leukemijos gydymo komplikacijų, kuri stipriai veikia tiek asmens fizinę būklę, tiek socialinị gyvenimą [5]. Dèl specifinio, ilgai trunkančio gydymo bei prastos savijautos vèžiu sergančių vaikų judejjimas yra ribotas. Išgyvenusiems po sèkmingo gydymo pacientams lieka fizinès būklès sutrikimų, kuriems įveikti negana ịprastinès fizinès veiklos, tačiau reikalingi specialūs kineziterapijos pratimai [6]. Siekiant išvengti komplikacijų vėlesniu laikotarpiu, ypač svarbu užtikrinti kuo optimalesnį šių asmenų fizinį aktyvumą. Vis dèlto nèra atlikta pakankamai tyrimų, kurie nustatytų kineziterapijos efektyvumą leukemija sergančių vaikų fizinei ir funkcinei būklei [7]. Todèl iškyla mokslinè problema - ištirti, kokị poveikị turi 8 savaičių kineziterapijos namų programos taikymas leukemija sergančių vaikų sąnarių amplitudèms, raumenų jègai, modifikuoto Keitel indekso bei „Stotis ir Eiti“ testo rezultatams.

Darbo tikslas: įvertinti 8 savaičių kineziterapijos namų programos efektyvumą leukemija sergančių vaikų fizinei būklei. 


\section{Tyrimo objektas ir metodai}

Iš viso tyrime dalyvavo 16 leukemija sergančių vaikų, tiriamujų amžiaus vidurkis $-10,81 \pm 3,83$ metai. Tyrimas buvo atliekamas Vilniaus universiteto Vaikų ligoninès onkohematologijos skyriuje nuo 2014 m. lapkričio iki 2015 $\mathrm{m}$. balandžio mènesio.

Tyrimui atlikti buvo panaudota centimetrinè juostelè, kuria išmatuotos kūno apimtys (šlaunų, liemens, dubens) bei krūtinès ląstos ekskursija. Tiriamujų pėdos dorzalinès fleksijos ir šlaunies vidinès bei išorinès rotacijų amplitudès matuotos goniometru. Pédos dorzalinę fleksiją ir blauzdos tiesimą atliekančių raumenų jèga vertinta pagal $R$. Lovett testą. Taip pat tiriamieji atliko 3 metrų „Stotis ir Eiti“ bei modifikuotą funkcinį judejjimo testus. Duomenų analizè atlikta naudojant statistinès analizès Excel 2007 bei „R-3.2.0 for Windows" programas.

Kūno antropometrinių duomenų vertinimo rezultatai ir jų aptarimas. Šlaunų apimtys. Tyrimo pradžioje pacientų kairès šlaunies apimčių vidurkis buvo $42,61 \pm 9,90 \mathrm{~cm}$, o dešinès $-42,74 \pm 9,89 \mathrm{~cm}$ ( 1 lentelè). Antro ištyrimo metu gauti rezultatai: kairès šlaunies apimčių vidurkis $-41,98 \pm 9,50 \mathrm{~cm}$, dešinès $-42,10 \pm 9,54 \mathrm{~cm}$. Kairès šlaunies apimčių vidutinè reikšmè sumažèjo $0,63 \pm 0,40 \mathrm{~cm}(1,49 \%)$, o dešinès šlaunies apimčių vidurkis sumažejo $0,64 \mathrm{~cm} \pm 0,35 \mathrm{~cm}(1,51 \%)$. Lyginant pirmo ir antro ištyrimo tiek kairès, tiek dešinès šlaunies apimčių vidutines reikšmes, nustatytas statistiškai reikšmingas skirtumas $(\mathrm{p}<0,05)$.

Liemens apimtys. Pirmo ištyrimo metu išmatavus tiriamujų liemens apimtis nustatytas liemens apimčių vidurkis buvo $67,24 \pm 9,62 \mathrm{~cm}$ (1 lentele). Lyginant pirmo ir antro ištyrimo metu išmatuotus liemens apimčiu vidurkius vidutinè reikšmè sumažejo $1,33 \pm 0,17 \mathrm{~cm}(1,99 \%)$. Nustatytas statistiškai reikšmingas skirtumas lyginant pirmo ir antro ištyrimo duomenų rezultatus $(\mathrm{p}<0,05)$.

Dubens apimtys. Pirmo ištyrimo metu leukemija sergan-

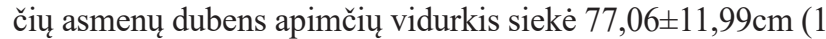
lentelè). Nustatytas dubens apimčių vidurkių skirtumas tarp pirmo ir antro ištyrimo siekè $1,29 \pm 0,12 \mathrm{~cm}(1,69 \%)$. Lyginant pirmo ir antro ištyrimo dubens apimčiu vidutines reikšmes, nustatytas statistiškai reikšmingas skirtumas $(\mathrm{p}<0,05)$.

Krūtinès ląstos ekskursija. Krūtinès ląstos ekskursija

1 lentelè. Leukemija sergančiu vaikų antropometriniai rodikliai I ir II ištyrimų metu

\begin{tabular}{|l|l|l|}
\hline Tirti rodikliai & I ištyrimas (cm) & II ištyrimas (cm) \\
\hline Kair. šlaunies apimtis & $42,61 \pm 9,90$ & $41,98 \pm 9,50$ \\
\hline Deš. šlaunies apimtis & $42,74 \pm 9,89$ & $42,10 \pm 9,54$ \\
\hline Liemens apimtis & $67,24 \pm 9,62$ & $65,91 \pm 9,79$ \\
\hline Dubens apimtis & $77,06 \pm 11,99$ & $75,77 \pm 11,87$ \\
\hline Krūtinės ląstos ekskursija & $3,78 \pm 1,49$ & $6,04 \pm 1,72$ \\
\hline
\end{tabular}

atspindi kvẻpavimo raumenų pajègumą ir krūtinès ląstos paslankumą. Pirmo ištyrimo metu krūtinès ląstos ekskursijos vidurkis buvo $3,78 \pm 1,49 \mathrm{~cm}$, o antro ištyrimo metu nustatytas vidurkis siekè $6,04 \pm 1,72 \mathrm{~cm}$ (1 lentelè). Pirmo ir antro ištyrimų vidurkių skirtumas yra 2,26 $\pm 0,23 \mathrm{~cm}(46,03 \%)$. Lyginant pirmo ir antro ištyrimo krūtinès ląstos ekskursijos vidutines reikšmes, nustatytas statistiškai reikšmingas skirtumas $(\mathrm{p}<0,05)$.

Judesių amplitudžių pokyčių vertinimo rezultatai ir jų aptarimas. Pédu dorzaline fleksija. Tyrimo pradžioje pacientų kairès pėdos dorzalinès fleksijos amplitudès vidurkis (laipsniais) buvo $4,50 \pm 5,18^{\circ}$, o dešinès $-3.81 \pm 5,64^{\circ}$ (2 lentelè). Antro ištyrimo metu gauti rezultatai: kairès pèdos dorzalinès fleksijos amplitudès vidurkis $-10,13 \pm 4,80^{\circ}$, dešinès $-9.81 \pm 4,53^{\circ}$. Kairès pèdos dorzalinès fleksijos amplitudès vidutinè reikšmè padidejo $5,63 \pm 0,38^{\circ}(76,96 \%)$. Lyginant pirmo ir antro ištyrimo kairès pèdos dorzalinès fleksijos laipsnių vidutines reikšmes, nustatytas statistiškai reikšmingas skirtumas $(\mathrm{p}<0,05)$. Dešinès pėdos dorzalinès fleksijos amplitudès vidutinès reiškmès padidèjimas siekè $6,00 \pm 1,10^{\circ}(88,12 \%)$. Lyginant pirmo ir antro ištyrimo dešinès pédos dorzalinès fleksijos laipsnių vidutines reikšmes, nustatytas statistiškai reikšmingas skirtumas $(p<0,05)$.

Stebimi ir išlikę ilgalaikiai neigiami čiurnos sąnario dorzifleksijos amplitudès pokyčiai. Ness ir kt. (2012) tyrime dalyvavo tiriamieji ( $n=415$, amžiaus vidurkis 35 metai), kuriems nuo leukemijos diagnozavimo buvo praèję $>10$ metų. $33,5 \%$ tiriamujų nustatyta $<5^{\circ}$ pédų dorzalinès fleksijos amplitudè. Taip pat tyrime teigiama, jog kumuliacine $\geq 215 \mathrm{mg} /$ $\mathrm{m}^{2}$ metotreksato dozé 3,4 karto padidina sumažejusią judesių amplitudžių riziką, lyginant su asmenimis, kuriems gydymas metotreksatu netaikomas. Tiriamieji, kurie gydymo metu gavo $\geq 39 \mathrm{mg} / \mathrm{m}^{2}$ kumuliacinę vinkristino dozę, turèjo 1,5 karto didesnę riziką sumažèjusioms judesių amplitudėms atsirasti, lyginant su tiriamaisiais, kuriems buvo skirta maŽesnè nei $39 \mathrm{mg} / \mathrm{m}^{2}$ kumuliacinè vinkristino dozè [8].

Šlaunu išorine rotacija. Tyrimo pradžioje pacientų kairès šlaunies išorinès rotacijos vidurkis (laipsniais) buvo $25,25 \pm 7,77^{\circ}$, o dešinès $-28,94 \pm 6,43$ (2 lentelè). Antro

2 lentelẻ. Leukemija sergančių vaikų sąnarių judesių amplitudžių pokyčiai

\begin{tabular}{|l|c|c|}
\hline Tirti rodikliai & $\begin{array}{c}\text { I ištyrimas } \\
\text { (laipsniai) }\end{array}$ & $\begin{array}{c}\text { II ištyrimas } \\
\text { (laipsniai) }\end{array}$ \\
\hline Kair. pėdos dorzaliné fleksija & $4,50 \pm 5,18$ & $10,13 \pm 4,80$ \\
\hline Deš. pėdos dorzalinė fleksija & $3,81 \pm 5,64$ & $9,81 \pm 4,53$ \\
\hline Kair. šlaunies išorinè rotacija & $25,25 \pm 7,77$ & $28,56 \pm 7,08$ \\
\hline Deš. šlaunies išorinė rotacija & $28,94 \pm 6,43$ & $31,38 \pm 5,73$ \\
\hline Kair. šlaunies vidinė rotacija & $26,00 \pm 8,07$ & $29,00 \pm 8,09$ \\
\hline Deš. šlaunies vidinè rotacija & $26,94 \pm 9,25$ & $29,63 \pm 8,80$ \\
\hline
\end{tabular}


ištyrimo metu kairès šlaunies išorinès rotacijos vidurkis buvo $28,56 \pm 7,08^{\circ}$, o dešinès $-31,38 \pm 5,73^{\circ}$. Kairès šlaunies išorinès rotacijos amplitudès vidutinè reikšmé padidejjo $3,31 \pm 0,69^{\circ}(12,3 \%)$. Lyginant pirmo ir antro ištyrimo kairès šlaunies išorinès rotacijos laipsnių vidutines reikšmes, nustatytas statistiškai patikimas skirtumas $(p<0,05)$. Dešinès šlaunies išorinès rotacijos amplitudès vidutinès reikšmès padidejimas siekè $2,44 \pm 0,71^{\circ}(8,09 \%)$. Lyginant pirmo ir antro ištyimo dešinès šlaunies išorinès rotacijos laipsnių vidutines reikšmes, nustatytas statistiškai patikimas skirtumas $(\mathrm{p}<0,05)$.

Šlaunu vidine rotacija. Tyrimo pradžioje pacientų kairès šlaunies vidinès rotacijos vidurkis (laipsniais) buvo $26,00 \pm 8,07^{\circ}$, o dešinès $-26,94 \pm 9,25^{\circ}$ (2 lentelè). Antro ištyrimo metu kairès šlaunies vidinès rotacijos vidurkis buvo $29,00 \pm 8,09^{\circ}$, o dešinès $-29,63 \pm 8,80^{\circ}$. Kairès šlaunies vidinès rotacijos amplitudès vidutinè reikšmé padidejjo $3,00 \pm 0,02^{\circ}$ $(10,91 \%)$. Lyginant pirmo ir antro ištyrimo kairès šlaunies vidinès rotacijos laipsnių vidutines reikšmes, nustatytas statistiškai patikimas skirtumas $(p<0,05)$. Dešinès šlaunies vidinès rotacijos amplitudès vidutinès reikšmès padidèjimas siekè $2,69 \pm 0,45^{\circ}(9,51 \%)$. Lyginant pirmo ir antro ištyrimo dešinès šlaunies vidinès rotacijos laipsnių vidutines reikšmes, nustatytas statistiškai patikimas skirtumas $(p<0,05)$.

3 lentelè. Leukemija sergančių vaikų raumenų jègos pokyčiai.

\begin{tabular}{|l|l|l|}
\hline Tirti rodikliai & $\begin{array}{l}\text { I ištyrimas } \\
\text { (balai) }\end{array}$ & $\begin{array}{l}\text { II ištyrimas } \\
\text { (balai) }\end{array}$ \\
\hline $\begin{array}{l}\text { Kair. pėdos dorzalinę fleksiją atlie- } \\
\text { kančių raumenų jėga }\end{array}$ & $3,68 \pm 0,23$ & $4,23 \pm 0,34$ \\
\hline $\begin{array}{l}\text { Deš. pėdos dorzalinę fleksiją atlie- } \\
\text { kančių raumenų jėga }\end{array}$ & $3,70 \pm 0,24$ & $4,27 \pm 0,35$ \\
\hline $\begin{array}{l}\text { Kair. blauzdos tiesimą atliekančių } \\
\text { raumenų jėga }\end{array}$ & $3,68 \pm 0,23$ & $4,25 \pm 0,26$ \\
\hline $\begin{array}{l}\text { Deš. blauzdos tiesimą atliekančių } \\
\text { raumenų jėga }\end{array}$ & $3,68 \pm 0,15$ & $4,25 \pm 0,19$ \\
\hline
\end{tabular}

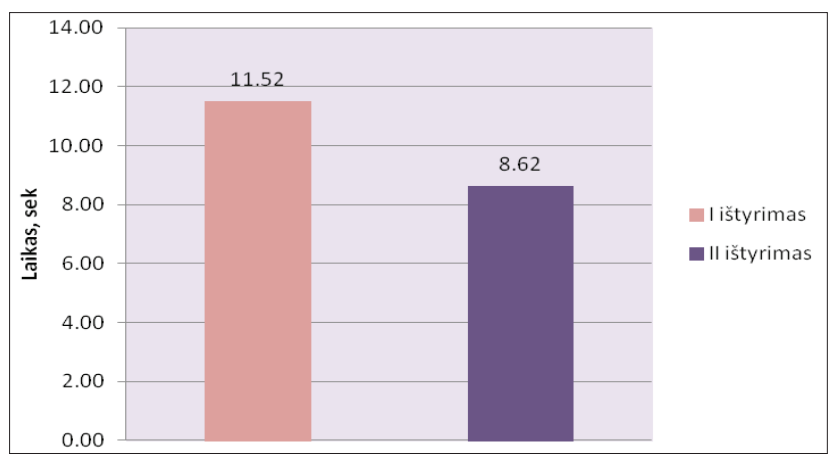

1 pav. Leukemija sergančių vaikų „Stotis ir Eiti“ testo atlikimo laikas sekundėmis pirmo ir antro ištyrimo metu
Teigiama, jog sumažèjusi šlaunų rotacijos amplitudè gali lemti kompensuojamuosius dubens judesius. Toks kompensacinis mechanizmas sukelia dažnesnius dubens judesius tam tikrais momentais ir atliekant tam tikrus judesius, kuomet pagrindinis judesys turetų būti šlaunies vidinè ar išorinè rotacija. Yra atlikta keletas tyrimų, kuriuose rastas ryšys tarp sumažejusių šlaunų rotacijos amplitudžių ir juosmeninès nugaros dalies skausmo [9].

Raumenų jègos duomenų pokyčių vertinimo rezultatai ir jų aptarimas. Pédu dorzaline fleksija atliekančiu raumenu jèga. Pirmo ištyrimo metu tiriamujų kairès pèdos dorzalinès fleksijos raumenu jègos vidurkis buvo 3,68 $\pm 0,23$ balai, dešinès $-3,70 \pm 0,24$ balai ( 3 lentelè). Antro ištyrimo metu tirtų asmenų kairès pèdos dorzalinès fleksijos raumenų jègos vidurkis buvo $4,23 \pm 0,34$ balai, o dešinès $-4,27 \pm 0,35$ balai. Tiriamujų kairès pėdos dorzalinę fleksiją atliekančių raumenų jègos pokyčio vidurkis buvo $0,54 \pm 0,11$ balo $(13,91 \%)$, o dešinès pèdos $-0,56 \pm 0,11$ balo $(14,3 \%)$. Gauti rezultatai rodo, jog tiek kairès, tiek dešinès pédos dorzalinę fleksiją atliekančių raumenų jèga statistiškai reikšmingai padidèjo $(\mathrm{p}<0,05)$.

Blauzdos tiesima atliekančiu raumenu jèga. Pirmo ištyrimo metu tiriamujų kairès blauzdos tiesimą atliekančių raumenų jègos vidurkis buvo 3,68 $\pm 0,23$ balai, o dešinès $3,68 \pm 0,15$ balai ( 3 lentelè). Antro ištyrimo metu tirtu asmenų kairès blauzdos tiesiamujų raumenų jègos vidurkis buvo $4,25 \pm 0,26$ balai, o dešinès $-4,25 \pm 0,19$ balai. Tiriamujų kairès blauzdos tiesimą atliekančiu raumenų jègos pokyčio vidurkis buvo $0,56 \pm 0,03$ balo (14,24\%), o dešinès blauzdos $-0,57 \pm 0,04$ balo $(14,27 \%)$. Gauti rezultatai rodo, jog tiek kairès, tiek dešinès blauzdos tiesimą atliekančių raumenų jëga statistiškai reikšmingai padidejo $(\mathrm{p}<0,05)$.

Juan ir kt. (2007) atlikto tyrimo metu leukemija sergantiems vaikams $(\mathrm{n}=7)$ taikyta 16 savaičiu kineziterapija, kurios

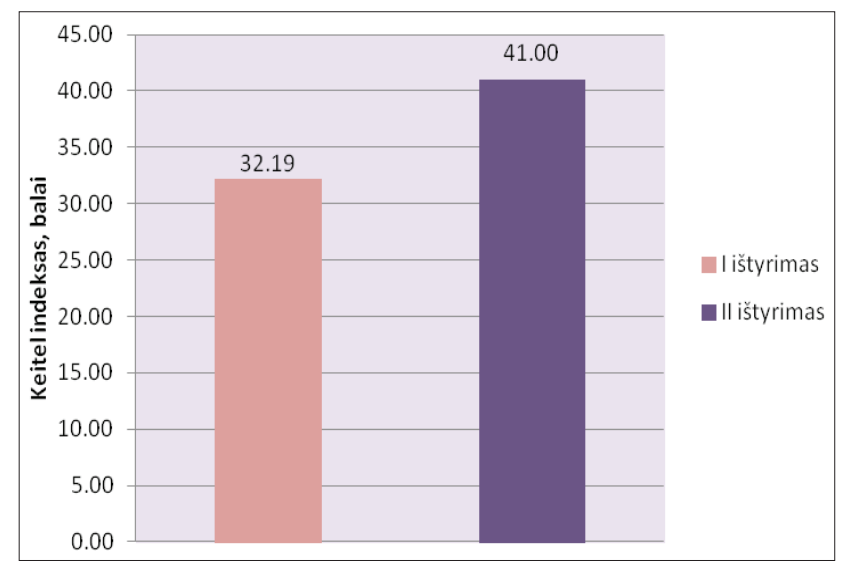

2 pav. Leukemija sergančių vaikų modifikuoto Keitel indekso balai pirmo ir antro ištyrimo metu 
metu taikyti raumenų jẻgą didinantys pratimai ir aerobinè treniruotė. Po 16 savaičių kineziterapijos procedūrų sekè 20 savaičių netreniruojamasis periodas. Tiriamieji tirti 3 kartus - prieš tyrimą, po 16 savaičių taikytos kineziterapijos ir po netreniruojamojo periodo. Po 16 savaičių taikytos kineziterapijos pastebèta statistiškai reikšmingai padidejusi viršutinių (žasto lenkimas ir tiesimas) ir apatinių galūnių (blauzdos tiesimas ir lenkimas, šlaunies tiesimas) raumenų jëga $(p<0,05)$. Nenustatytas statistiškai reikšmingas raumenų jègos sumažèjimas po 20 savaičių netreniruojamojo periodo [10].

Brusel ir kt. (2006) tyrime matuota leukemija išgyvenusių asmenų ( $\mathrm{n}=13$, amžiaus vidurkis - 15,5 metų) raumenų jèga, kuri lyginama su kontrolinès grupès raumenų jègos rezultatais. Raumenų jègai (žasto atitraukimas, blauzdos tiesimas, pėdos dorzalinè fleksija, riešo tiesimas ir šlaunies lenkimas) matuoti buvo pasitelktas rankinis dinamometras (Citex dynamometer CT, C.I.T. Technics, Groningen, the Netherlands). Tyrimo metu nustatyta, jog praejus 5-6 metams po leukemijos gydymo, statistiškai reikšmingai $(\mathrm{p}<0,05)$ sumažèjusi tik blauzdos tiesimą atliekančių raumenų jẻga $(252,1 \pm 81,13 \mathrm{~N})$. Tuo tarpu nenustatyta žasto atitraukimą $(\mathrm{p}=0,1)$, pėdos dorzalinę fleksiją $(\mathrm{p}=0,25)$, riešo tiesimą $(\mathrm{p}=0,8)$ ir šlaunies lenkimą $(\mathrm{p}=0,6)$ atliekančių raumenų jègos statistiškai reikšmingo sumažèjimo [11].

„Stotis ir Eiti“" testo pokyčių vertinimo rezultatai ir jų aptarimas. Testas „Stotis ir Eiti““ (3 m). Ištyrimo metu buvo atliekamas „Stotis ir Eiti“ testas. Testo rezultatu vidurkis pirmo ištyrimo metu buvo $11,52 \pm 0,94$ sek., $o$ antro ištyrimo metu vidutinè trukmè $8,62 \pm 1,28$ sek. (1 pav.). Pirmo ir antro

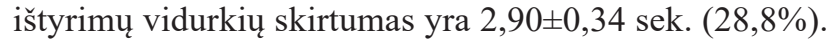
Lyginant pirmo ir antro ištyrimo „Stotis ir Eiti“ testo vidutines reikšmes, nustatytas statistiškai reikšmingas skirtumas $(\mathrm{p}<0,05)$.

Pagal Juan ir kt. (2007) atliktą tyrimą ir gautus rezultatus, teigiama, jog 8 savaičių trukmès (3 k. per savaitę, po 90-120 min. per užsièmimą) kineziterapijos procedūros yra pakankamas laiko tarpas pasiekti statistiškai reikšmingą „,Stotis ir Eiti“" testo rezultatu pagerèjimą leukemija sergantiems vaikams [12].

Modifikuoto Keitel indekso pokyčiu vertinimo rezultatai ir jų aptarimas. Modifikuotas Keitel indeksas. Modifikuoto Keitel indekso pirmojo tyrimo metu vidurkis $-32,19 \pm 2,54$ balo (71,53\% nuo maksimalios balų sumos) (2 pav.). Antro tyrimo metu vidurkis $-41,00 \pm 1,41$ balo $(91,11 \%$ nuo maksimalios balų sumos). Pirmo ir antro ištyrimų rezultatų vidurkių skirtumas yra $8,81 \pm 1,12$ balo $(24,07 \%)$. Lyginant pirmo ir antro ištyrimo modifikuoto Keitel indekso vidutines reikšmes, nustatytas statistiškai reikšmingas skirtumas $(\mathrm{p}<0,05)$.
Išsikelta hipotezè darbo pradžioje pasitvirtino - kineziterapijos namų programos taikymas 8 savaites leukemija sergantiems vaikams pakoreguoja tiriamuju antropometrinius duomenis, padidina judesių amplitudes ir raumenų jègą bei pagerina modifikuoto Keitel indekso ir „Stotis ir Eiti“ testo rezultatus.

\section{Išvados}

Po 8 savaičių kineziterapijos namų programos taikymo leukemija sergantiems vaikams statistiškai reikšmingai padidejo krūtinès ląstos ekskursija, vertintų sąnarių judesių amplitudès, raumenų jèga, pagerejo "Stotis ir Eiti" testo bei modifikuoto Keitel indekso rezultatai. Gauti rezultatai leidžia daryti prielaidą apie pagerèjusią tiriamųu pusiausvyrą bei funkcinę būklę.

\section{Literatūra}

1. Tai EW, Ward KC, Bonaventure A, Siegel DA, Coleman MP. Survival among children diagnosed with acute lymphoblastic leukemia in the United States, by race and age, 2001 to 2009: Findings from the CONCORD-2 study. Cancer 2017 Dec 15;123(24):5178-5189.

https://doi.org/10.1002/cncr.30899

2. Ward E, De Santis C, Robbins A, Kohler B and Jemal A. Childhood and adolescent cancer statistics. CA: A Cancer Journal for Clinicians 2014; 64: 83-103.

https://doi.org/10.3322/caac.21219

3. Ighetti L, Bruzzi P, Predieri B, Paolucci P. Obesity in patients with acute lymphoblastic leukemia in childhood. Ital J Pediatr 2012 Jan; 27;38:4.

4. Wright M, Bryans A, Gray K, Skinner L and Verhoeve A. Physical activity in adolescents following treatment for cancer: influencing factors. Leukemia research and treatment, 2013; Article ID 592395: 1-7.

5. Tay CG, Lee VWM, Ong LC, Goh KJ, Ariffin H, Fong CY. Vincristine-induced peripheral neuropathy in survivors of childhood acute lymphoblastic leukaemia. 2017 Aug;64(8). doi: 10.1002/pbc.26471. Epub 2017 Jan 31.

https://doi.org/10.1002/pbc.26471

6. Hoffman MC, Mulrooney DA, Steinberger J, Lee J, Baker KS, Ness KK. Deficits in physical function among young childhood cancer survivors. J Clin Oncol 2013 Aug 1;31(22):2799-805. https://doi.org/10.1200/JCO.2012.47.8081

7. Braam K, van der Torre P, Takken T, Veening MA, van Dulmen-den Broeder E, Kaspers GJ. Physical exercise training interventions for children and young adults during and after treatment for childhood cancer. 2016 Mar 31;3:CD008796.

8. Ness KK, Hudson MM, Pui CH, Green DM, Krull KR, Huang TT. et al. Neuromuscular impairments in adult survivors of childhood acute lymphoblastic leukemia: associations with physical performance and chemotherapy doses. Canser 2012. 1;118(3):828-38. 
9. Harris-Hayes M, Sahrmann SA, Van Dillen LR. Relationship between the hip and low back pain in athletes who participate in rotation-related sports. J Sport Rehabil 2009; 18(1): 60-75. https://doi.org/10.1123/jsr.18.1.60

10. San Juan AF, Fleck SJ, Chamorro-Vina C, Mate-Munoz JL, Moral S, Garcia-Castro J. et al. Early-phase adaptations to intrahospital training in strength and functional mobility of children with leukemia. J Strength Cond Res 2007; 21(1):173-7. https://doi.org/10.1519/00124278-200702000-00031

11. Van Brussel M, Takken T, van der Net J, Engelbert RH, Bierings $\mathrm{M}$, Schoenmakers MA. et al. Physical function and fitness in long-term survivors of childhood leukaemia. Pediatr Rehabil 2006; 9(3):267-74.

https://doi.org/10.1080/13638490500523150

12. San Juan AF, Fleck SJ, Chamorro-Vina C, Mate-Munoz JL, Moral S, Perez M. et al. Effects of an intrahospital exercise program intervention for children with leukemia. Medicine and Science in Sports and Exercise 2007; 39(1):13-21.

https://doi.org/10.1249/01.mss.0000240326.54147.fc

\section{THE INFLUENCE OF PHYSIOTHERAPY HOME PROGRAM ON PHYSICAL AND \\ FUNCTIONAL CONDITION IN PEDIATRIC PATIENTS WITH LEUKEMIA \\ G. Juškẻnienė, K. Miliškevičiūtė, A. Šidlauskienė}

Key words: oncohematology, pediatrics, leukemia, physiotherapy, muscle strength, range of motion, functional condition.

Summary

The aim of research work: to assess the efficiency of physiotherapy's home-based exercise program on pediatric patients with leukemia.
Materials and methods: 16 pediatric patients with leukemia aged $10,81 \pm 3,83$ on average participated in the research carried out at The Children's Oncohaematology Department of Children's Hospital, Affiliate of Vilnius University Hospital Santaros Clinics from November, 2014 to April, 2015.

Measuring-tape was used to measure particular body parts like thighs, waist and pelvis, height, as well as while assessing thorax excursion. Range of motion of ankle dorsiflexion and hip internal and external rotations were measured by goniometer. The muscles that produce ankle dorsiflexion and knee extension were measured accordingly R.Lovett's test. Participants of the research also performed "Timed Up and Go" test, modified Keitel index was also assessed.

Excel 2007 and R (The R Project for Statistical Computing, 2012) were used to process the data of the research.

Results: A two months (8 weeks) home based physiotherapy program intervention for pediatric patients with leukemia is an effective tool in order to adjust anthropometric measurments, improve range of motion and muscle strength, improve "Timed Up and Go" test and modified Keitel index.

Conclusions: 8 weeks home based physiotherapy's program intervention for pediatric patients with leukemia statistically significant increased the thorax excursion, decreased the circumferences of thighs, waist and pelvis, improved the active ranges of motion and muscle strength, showed better results of „Timed Up and Go“ test and modified Keitel index, which lets us make assumptions about improved balance and functional condition of the participants.

Correspondence to: giedre.jus@gmail.com

Gauta 2017-12-21 